\title{
Starting the Third Decade: Reaching Further and Deeper
}

\author{
Douglas McDougall ${ }^{1}$ (D)
}

Accepted: 26 March 2021/Published online: 12 April 2021

(C) Ontario Institute for Studies in Education (OISE) 2021

It is my great pleasure to write this first editorial for the start of the third decade of the journal. For each editorial, I decide on how I want to organize the manuscripts in the issue. In many cases, I write about each paper in the order that they appear in the journal. In some editorials, I cluster the papers around different themes. In this issue, I explore five themes: science, mathematics, technology, STEM, and university undergraduate studies.

There are four papers that have a science theme. Zhang \& Cobern (2020) wrote in response to the Aditomo \& Klieme (2020) article about forms of inquiry-based science instructions. They review studies about critical issues regarding teacher guidance and identify patterns across countries. They pose a series of questions that further the discussion raised by the article. Finally, they provide the reader with some future research directions to help clarify and address multi-faceted inquiry teaching. Kurup et al. (2021) investigated informed decision making by Grade 9 students in the UK as they learned about global warming and climate change. An inquiry intervention model was developed to identify beliefs, understanding, and knowledge base. The students in this study developed an understanding of the causes and effects of global warming. The authors note that the regular UK science school curriculum does not contain specific references to socio-scientific issues, and so, this makes it difficult to provide opportunities for informed decision making. This paper makes a strong argument for the revision of science curricula to ensure that there are opportunities to explore the socio-scientific issues where they do not currently exist.

The Guedj \& Urgelli (2021) paper investigates the interaction and relationships between school, museums, and other scientific cultural places. They wish to better explain the conditions for various partnerships in science education. They look at the scientific mediation practices between the school and its partners in both formal and informal educational settings. They describe an approach where teachers can investigate socio-scientific questions from new perspectives and recognize the models that they adopt. Rennie (2021) also explores museums through a review of the Pedretti \& Navas Iannini (2020) book Controversy in Science Museums: Re-imagining Exhibition Spaces and Practice. Rennie reviews how critical exhibitions challenge the nature of science museums and how to transform science museums

Douglas McDougall

doug.mcdougall@utoronto.ca

1 Ontario Institute for Studies in Education, University of Toronto, 252 Bloor Street West, Toronto, Ontario, Canada 
to focus on serious socio-scientific issues. The book is written by knowledgeable and experienced researchers with an interaction between theory, practice, and research to provide leaders with a practical analysis for the future transformation of science museums and critical exhibitions. These two papers further illustrate the importance of science learning in formal and informal places.

There are three papers that explore mathematics at the K-12 level. Lagrange (2021) is interested in the design of modeling activities in mathematics and other scientific disciplines. He looked at how modeling can serve as a foundation of mathematical concepts. He studied a general question and then offered high school students tasks to explore models. He uses a theoretical framework of connected spaces. Even though some of the situations were quite complex, the students were able to understand the models and underlying concepts. He leaves us with a number of questions, specifically which models to use and what tasks to propose. In another paper, Martin et al. (2021) provide an analysis of probability tasks in three elementary school mathematics textbooks in Quebec. They provided descriptive statistical analysis of 267 probability tasks and investigated five tasks in depth. They look at the origin of the tasks, the size of the sample, and the interpretations of the results. They describe the need to support the development of these tasks and the teachers' didactic intentions that guide the learning experiences. In the third paper, Milewski et al. (2021) write about teacher noticing and decision making. They introduce the concept of conditional construals to illustrate the moments when teachers need additional context to judge the appropriateness of a teaching action. They use the identification of these moments to study the type of reasoning used by the teacher so they can be better informed about the information that teachers need to make decisions.

There is one article that focuses on STEM education. Kwon et al. (2021) investigated the effect of project-based learning activities in STEM with middle and high school students attending a 1- or 2-week summer camp. The students completed surveys on problem-solving beliefs and STEM semantics. They found that informal STEM project-learning activities improve their STEM perceptions. They also found that students' problem-solving beliefs could directly influence students' STEM career perceptions. These findings illustrate the importance of STEM activities in informal settings. Imagine their effect if our schools engaged in more STEM project-based learning activities.

There are two papers in this issue that focus on university undergraduate mathematics education. Lane et al. (2021) investigate the use of blended learning (BL), which combines online learning with face-to-face learning. They analyzed student and instructor feedback from surveys and interviews from science courses in university. They found that emotional engagement is a good predictor of student satisfaction and success. They encourage instructors to use collaborative learning strategies and to maintain a personal connection with the students. In the COVID-19 teaching environment, opportunities to enhance student experience and reduce challenges to teaching and learning are very important. This study gives us insights into the blended learning teaching format that could be extended to all online learning environments. In a study of first-year university students in Calculus mathematics classes, O'Shea \& Breen (2021) investigated the differences between mathematics at school and at university. Non-routine tasks were used to consider their views on the differences and the type of task on either side of the transition. They found a dual role in use of mathematics tasks: they are used to make the instructor's expectations clear to the students as well as providing opportunities for students to develop mathematical thinking skills. The authors also suggest that these benefits and roles can be found in other mathematical topics other than Calculus.

There are two papers that focus on technology with preservice teachers. Bayage et al. (2021) explored university faculty perceptions on preservice teachers' use of information and communication technology (ICT). The authors found that, although the preservice teachers were exposed to ICT, there remain challenges that inhibit ICT use by the preservice teachers. One challenge is the lack of agreement on how to prepare the preservice teachers to use technology in their classrooms. Embedded in this challenge is the observation that university faculty has different opinions on their own use of ICT and its 
implementation in the program. Kahraman (2021) investigated the effects of blog-based learning on preservice science teachers' Internet self-efficacy and their understanding of atmosphere-related environmental problems. Groups of students were asked to perform activities to access documents, prepare a presentation, share findings, and develop a blog. The use of writing in science classrooms is important to facilitate students' conceptual understanding of science concepts. Blogs are a good way to encourage writing about science concepts. This study found that blog-based learning had a positive effect on students' understanding of atmosphere-related environmental problems.

This issue starts our journey into the third decade. We look for ways to extend our reach into other countries, areas of research, and education ideas in formal and informal spaces. We look forward to your participation as a reader, author, and reviewer of the Canadian Journal of Science, Mathematics, and Technology Education.

\section{Declarations}

Conflicts of interest The author declares no competing interests.

\section{References}

Aditomo, A., \& Klieme, E. (2020). Forms of inquiry-based science instruction and their relations with learning outcomes: Evidence from high and low-performing education systems. International Journal of Science Education, 42(4), 504-525.

Bayage, A., Bossé, M.J., Sevier, J., Fountain, C., Williams, D., Bosire, S., \& Blignaut, S. (2021). University Faculty Opinions on Preservice Teachers' Technological Readiness. Canadian Journal for Science, Mathematics, and Technology Education, 21(1). https://doi.org/10.1007/s42330-021-00138-6

Guedj, M., \& Urgelli, B. (2021). L'interface éducation formelle et non formelle: un chantier en partage pour l'éducation scientifique. Canadian Journal for Science, Mathematics, and Technology Education, 21(1). https://doi.org/10.1007/ s42330-020-00126-2

Kahraman, S. (2021). The effects of blog-based learning on pre-service science teachers' Internet self efficacy and understanding of atmosphere-related environmental issues. Canadian Journal for Science, Mathematics, and Technology Education, 21(1). https://doi.org/10.1007/s42330-021-00137-7

Kurup, P., Levinson, R., \& Li, X. (2021). Informed-decision regarding global warming and climate change among high school students in the United Kingdom. Canadian Journal for Science, Mathematics, and Technology Education, 21(1). https://doi.org/10.1007/s42330-020-00123-5

Kwon, H., Capraro, R. M., \& Capraro, M. M. (2021). When I Believe, I Can: Success STEMs from My Perceptions. Canadian Journal for Science, Mathematics, and Technology Education, 21(1). https://doi.org/10.1007/ s42330-020-00132-4

Lagrange, J-B. (2021). Les espaces de travail connectés: une perspective nouvelle pour la modélisation dans le secondaire? Canadian Journal for Science, Mathematics, and Technology Education, 21(1). https://doi.org/10.1007/ s42330-020-00130-6

Lane, S., Hoang, J. G., Leighton, J. P., \& Rissanen, A. (2021). Engagement and Satisfaction: mixed-method analysis of blended learning in the sciences. Canadian Journal for Science, Mathematics, and Technology Education, 21(1). https://doi.org/10.1007/s42330-021-00139-5

Martin, V., Héroux, S, Homier, M., \& Thibault, M. (2021). L'analyse des tâches probabilistes proposées dans des cahiers d'apprentissage destinés à l'enseignement-apprentissage des mathématiques au primaire au Québec: exemplification de tâches inscrites dans l'approche fréquentielle. Canadian Journal for Science, Mathematics, and Technology Education, 21(1). https://doi.org/10.1007/s42330-021-00134-w

Milewski, A. M., Erickson, A. W., \& Herbst, P. G. (2021). It depends": Using ambiguities to better understand mathematics teachers' decision-making. Canadian Journal for Science, Mathematics, and Technology Education, 21(1).https:// doi.org/10.1007/s42330-021-00141-X

O'Shea, A., \& Breen, S. (2021). Students' views on transition to university: the role of mathematical tasks. Canadian Journal for Science, Mathematics, and Technology Education, 21(1). https://doi.org/10.1007/s42330-021-00140-y

Pedretti, E., \& Navas Iannini, A.M. (2020). Controversy in Science Museums: Re-imagining Exhibition Spaces and Practice (1st ed.). Routledge. https://doi.org/10.4324/9780429507588 
Rennie, L. J. (2021). Controversy and Critical Exhibitions: Envisioning a fourth generation of science museums. Canadian Journal for Science, Mathematics, and Technology Education, 21(1). https://doi.org/10.1007/s42330-021-00142-w

Zhang, L., \& Cobern, W. W. (2020). Confusions on "Guidance" in Inquiry-Based Science Teaching: A Response to Aditomo and Klieme (2020). Canadian Journal for Science, Mathematics, and Technology Education, 21(1). https:// doi.org/10.1007/s42330-020-00116-4

Publisher's Note Springer Nature remains neutral with regard to jurisdictional claims in published maps and institutional affiliations. 